\title{
Firm Characteristics and Compliance with International Financial Reporting Standards (IFRS) by Listed Financial Services Companies in Nigeria
}

\author{
Ioraver N. Tsegba ${ }^{1}$, Joy Semberfan ${ }^{2}$, Gabriel M. Tyokoso ${ }^{3}$ \\ ${ }^{1}$ Federal University of Agriculture, Makurdi, Nigeria \\ ${ }^{2}$ Nigerian College of Accountancy, Jos, Nigeria \\ ${ }^{3}$ Federal University of Agriculture, Makurdi, Nigeria \\ Correspondence: Ioraver N. Tsegba, Federal University of Agriculture, Makurdi, Nigeria.
}

Received: December 16, 2016

doi:10.11114/afa.v3i1.2196
Accepted: January 31, 2017

Available online: February 5, 2017

URL: http://dx.doi.org/10.11114/afa.v3i1.2196

\begin{abstract}
This study investigated the level of compliance with International Financial Reporting Standards (IFRS) by listed financial services companies in Nigeria, and the effect firm characteristics have on the level of compliance. The study also examined whether compliance with IFRS significantly differs between listed Deposit Money Banks (DMB) and Insurance Companies (INC) in Nigeria. Secondary data used for the study were extracted from the annual report and accounts of the sampled firms and analyzed using the multiple regression technique and Wilcoxon Rank Sum Test for two independent samples. The study found that (i) the level of compliance with IFRS by the sampled firms is high (about 85.9\%); (ii) profitability is positive and significantly associated with IFRS at $10 \%$ level; (iii) firm size and auditor type are positive but insignificantly associated with IFRS compliance; and (iv) leverage and internationality are negative and insignificantly associated with IFRS compliance. Furthermore, the study found that compliance with IFRS by DMB is higher than INC but the difference is not statistically significant. The major conclusion reached in this study was that compliance with IFRS by listed financial services companies in Nigeria is not driven by firm attributes. The study recommended that adequate steps be taken by regulatory authorities such as the Financial Reporting Council (FRC) of Nigeria to ensure full compliance with the mandatory disclosure requirements of IFRS by listed firms in Nigeria.
\end{abstract}

Keywords: international financial reporting standards, corporate compliance, financial services companies, deposit money banks, insurance companies, Nigeria

\section{Introduction}

Nigeria's adoption of IFRS for all listed companies with effect from I January, 2012 generated a lot of concerns because the adoption was sudden and without consultation with the relevant key stakeholders such as the practitioners, the regulatory agencies and the academics (Herbert, Tsegba, Ohanele, \& Anyahara, 2013). IFRS are construed to be a single set of high quality, principles-based standards prepared for general purpose uses (Herbert, 2010). IFRS are considered "principles based" set of standards in that they establish broad rules as well as dictate specific treatments. They comprise of four components of documents, namely: International Accounting Standards (IAS), IFRS, the Standing Interpretation Committee Statements (SICS), and the International Financial Reporting Issues Committee Statements (IFRICS). IFRS are designed to encourage professional judgment and discourage over reliance on detailed rules (Azobu, 2010). They purport to be set of rules that ideally would apply equally to financial reporting by public companies worldwide.

A number of affirmative reliefs have been attributed to the use of uniform reporting standards exemplified by IFRS (Herbert, 2010; Herbert \& Tsegba, 2013). The first affirmative argument which relates to scale economies underlies all forms of uniform contracting. It is argued that uniform rules need only be introduced once because they constitute a type of public good, in that the marginal cost of an additional user adopting them is zero and nobody is disadvantaged by another using them. The second advantage of uniform standards is the protection they give auditors against managers playing an opinion 'shopping game' (Ball, 2006). The third advantage is the potential of eliminating informational 
externalities arising from lack of comparability among others. The fourth advantage derives from the worldwide support from multinational corporations (MNCs), regulators and users because of the belief that common standards in the preparation of corporate financial statements will facilitate international comparability from different countries. The fifth benefit is the belief that in a truly global economy, finance professionals will be more mobile, and companies will more easily respond to human capital needs around the world.

The opponents of IFRS hinge their arguments on the following: First, it is not clear that uniform financial reporting quality requires uniform accounting rules (the 'one size fits all') (Ball, 2006). Second, to develop a fully detailed set of accounting standards to cover every feasible contingency is a costly venture, so standards are not the only way of solving accounting method choices (Herbert \& Tsegba, 2013). Third, costs of adoption may be very high and some firms may not be able to afford them. These costs include staff training and education of personnel on how to prepare financial statements using IFRS principles (Nobes, 2006). Fourth, there appears to be some concerns that many countries that claim to be converging to IFRS may never get 100\% compliance (Herbert \& Tsegba, 2013).

The mixed arguments for and against IFRS adoption makes the subject amenable to empirical research by many researchers such as Ibrahim (2006), Juhmani (2012), Palmer (2013), Demir and Bahadir (2014), and Saidu and Dauda (2014) to determine the levels of compliance with IFRS in adopting jurisdictions. However, most of these studies are from foreign literature. Studies from Nigeria are relatively few largely due to the early mandatory adoption of IFRS by listed Nigerian companies. Besides, prior studies document mixed results of the association between the level of disclosure and company characteristics such as company size, leverage, profitability, company age and auditor type. For example, Ali, Ahmed and Henry (2004), Al-Shammari (2011), and Juhmani (2012) found a positive and significant influence of company size on the level of compliance with IFRS, while Glaum and Street (2003) and Demir and Bahadir (2014) reported insignificant relationship. Understandably, the mixed results could be explained by methodological differences but they still remain a cause for empirical concerns.

In addition, the few Nigerian studies on IFRS are either in relation to DMB or INC and not focused on the whole financial services companies. The study focuses on two financial services companies, namely banks and insurances companies to gauge the extent to which compliance with the mandatory requirements of IFRS can be established in Nigeria for three main reasons. First, as providers of funds for financing of the various activities in the economy, financial services companies constitute the engine of economic growth and whatever happens to them has spiral effect on the whole economy. Second, the financial services companies are in the eye of the national and international community because they hold their deposits in varying forms and magnitudes. Third, the financial services companies, especially the banks, had started complying with the disclosure requirements of IFRS before the mandatory date of January 1, 2012 took effect. They, therefore, offer themselves as the preferred domain for this investigation which seeks to establish how far they have gone in their IFRS compliance.

This study is motivated by three factors. First, it is often alleged that listed companies in emerging nations that are under pressure to improve their quality of corporate financial reporting, do not fully comply with the disclosure requirements stipulated by the regulatory agencies (Akhtaruddin, 2005). Second, the government regulatory bodies and the accountancy profession of emerging nations suffer from structural weaknesses and often take a lenient attitude towards default of accounting regulations (Ali, Ahmed \& Henry, 2004). Consequently, the study assesses the association between compliance with IFRS and size, profitability, leverage, internationality and type of auditor of financial services companies in Nigeria. The use of these proxies is in line with prior studies of Glaum and Street (2003), Fekete, Matis and Lukacs (2008), Al-Mutawaa and Hewaidy (2010), Palmer (2013) and Demir and Bahadir (2014). The study hypothesized as follows: (1) firm size, profitability, leverage, internationality and auditor type are not significantly associated with IFRS compliance by listed financial services companies in Nigeria. (2) There is no significant difference in the IFRS compliance between listed DMB and INC in Nigeria.

The study is anchored on two theories which provide justification for compliance with accounting standards adopted in a given jurisdiction, namely the agency theory and the signaling theory. The agency theory parley resonates from the fears expressed about the separation of ownership and control in a modern corporation by Smith (1776) and further re-echoed by Veblen (1924). The theory, propounded by Jensen and Meckling (1976), provides an explanation of the agency relationship between parties who are entrusted with the day to day management of the firm, especially with regard to accounting information namely the principal (the shareholders or owners of the firm) and the agents (managers) (Kam, 1990). The agency theory assumes that managers will act opportunistically to further their own interest before shareholders rather than maximizing the returns due to them, and that a fundamental tension exists between the owners (principal) and the agents (managers) (Dockery, Herbert \& Taylor, 2000).

A number of arguments have linked the agency theory to the nature and magnitude of information managers elect to disclose to the stakeholders. First, it is argued that managers tend to increase the amount of information provided to the owners as a means of reducing the owners' interference and to improve their positions, especially when they carry out 
their work properly (Belkaoui \& Karpik, 1989). Second, managers may be motivated to disclose as much information as possible in order to differentiate themselves from poorly run corporations (Lev \& Penman, 1990; Watson, Shrives \& Marston, 2002). Third, management may use corporate disclosure as a means of mitigating agency problems associated with informational asymmetry, a situation where one party to the contract has more information than the other parties to the same contract (Jensen \& Meckling 1976; Healy \& Palepu, 2001). Consistent with these affirmative arguments for corporate disclosure and compliance with a given set of accounting standards, this study is of the view that that managers are under voluntary obligation to comply with IFRS, but their compliance levels may be affected by a tradeoff between cost of compliance and cost of sanctions emanating from partial or non-compliance.

The signaling theory provides an explanatory framework for corporate disclosure (Watson, Shrives \& Marston, 2002). It is argued that companies that perform better than others may have more incentives to disclose more information to signal their good performance and screen themselves from companies performing less well (Akerlof, 1970).

The rest of the paper is structured as follows: section 2 reviews the empirical literature, section 3 presents the methodology, section 4 presents and discusses the results, and section 5 covers the conclusion and recommendations.

\section{Review of Empirical Literature}

The empirical literature on compliance with IFRS in Nigeria appears to be scanty. A study by Saidu and Dauda (2014), which assesses the extent to which quoted banks in Nigeria complied with the requirements as captured in IFRS 1: First Time Adoption of IFRS, however, provides a representative case for this review. This ex-post facto and survey research design, sourced data from structured questionnaire and 2014 audited financial reports of the sampled banks. The Qualitative Grading System (QGS) was employed in determining the degree of compliance of the banks while Multivariate regression and Chi-square tests were used in measuring the effect of the factors responsible for compliance, and the difficulties encountered in the compliance process respectively. The results obtained from their study informed the conclusion that the Nigerian banking industry does not fully comply with the requirements of IFRS-framework. The mean compliance reported in their study is $74 \%$ which falls in the semi-strong compliance level articulated by the study. Their study also found amenability, globalization and response to users' needs as factors significantly influencing the compliance level of Nigerian banks with IFRS-framework. The import of Saidu and Dauda's (2014) study resides in the mean compliance level as other variables investigated, such as amenability and response to users' needs, are not included in this present study.

The summaries of the results of investigations into the effect of firms characteristics on compliance with IFRS in other jurisdictions, such as Australia, Germany, Hungary, Kuwait, and Turkey, are presented in Table 1. Though limited to a few countries, the studies give a bird's view of the possible effect of firm characteristics on compliance with the mandatory disclosure requirements of IFRS. 
Table 1. Summary of Empirical Evidence Linking Firm Size and Compliance with IFRS Mandatory Disclosure Requirements

\begin{tabular}{|c|c|c|}
\hline Corporate Size & & \\
\hline Author(s) & Country & Results \\
\hline Glaum \& Street (2003). & Germany & Company size not significantly related to level of compliance with IFRS. \\
\hline $\begin{array}{l}\text { Ali, Ahmed \& Henry } \\
\text { (2004) }\end{array}$ & $\begin{array}{l}\text { South Ásia (India, Pakistan } \\
\& \text { Bangladesh) }\end{array}$ & Compliance levels are positively related to company size. \\
\hline Ibrahim (2006) & 6 Middle East Countries & Company size significantly associated with level of compliance with IFRS. \\
\hline $\begin{array}{l}\text { Fekete, Matiş \& } \\
\text { Lukács (2008) }\end{array}$ & Hungary & Company size statistically associated with level of compliance with IFRS. \\
\hline $\begin{array}{l}\text { Al Mutawaa \& } \\
\text { Hewaidy }(2010)\end{array}$ & Kuwait & $\begin{array}{l}\text { Company size has significant positive association with level of compliance with IAS-led } \\
\text { (IFRS) disclosure requirements. }\end{array}$ \\
\hline Al-Shammari (2011) & Kuwait & Compliance levels positively related to company size. \\
\hline Juhmani (2012) & Bahrain & $\begin{array}{l}\text { Company size has a significant positive relationship with the level of compliance with } \\
\text { mandatory IFRS disclosure requirements. }\end{array}$ \\
\hline Palmer (2013) & Australia & A positive relationship between the extent of disclosure and company size. \\
\hline $\begin{array}{l}\text { Demir } \\
(2014)\end{array} \quad \& \quad$ Bahadir & Turkey & Company size not significantly related to compliance with IFRS. \\
\hline $\begin{array}{l}\text { A. Profitability } \\
\text { Author(s) }\end{array}$ & Country & Results \\
\hline $\begin{array}{l}\text { Ali, Ahmed \& Henry } \\
\text { (2004) }\end{array}$ & South Asia & Compliance levels are positively related to profitability. \\
\hline $\begin{array}{l}\text { Al Mutawaa \& } \\
\text { Hewaidy }(2010\end{array}$ & Kuwait & $\begin{array}{l}\text { Profitability has no significant association with level of compliance with IAS-led (IFRS) } \\
\text { disclosure requirements. }\end{array}$ \\
\hline Juhmani (2012) & Buhrain & Profitability found to be insignificant in explaining compliance with IFRS. \\
\hline Palmer (2013) & Australia & $\begin{array}{l}\text { A positive relationship between the extent of disclosure and profitability, leverage and } \\
\text { auditor size. }\end{array}$ \\
\hline $\begin{array}{l}\text { Demir } \\
(2014)\end{array} \quad \& \quad$ Bahadir & Turkey & Profitability not significantly related to compliance with IFRS. \\
\hline $\begin{array}{c}\text { B. Leverage } \\
\text { Author(s) }\end{array}$ & Country & Results \\
\hline $\begin{array}{l}\text { Ali, Ahmed \& Henry } \\
\text { (2004) }\end{array}$ & South Asia & Leverage is found to be insignificant in explaining the compliance level. \\
\hline $\begin{array}{l}\text { Al Mutawaa \& } \\
\text { Hewaidy }(2010)\end{array}$ & Kuwait & $\begin{array}{l}\text { Leverage has no significant association with level of compliance with IAS-led (IFRS) } \\
\text { disclosure requirements. }\end{array}$ \\
\hline Juhmani (2012) & Buhrain & Leverage found to be insignificant in explaining compliance with IFRS \\
\hline Palmer (2013) & Australia & A positive relationship between the extent of disclosure and leverage. \\
\hline $\begin{array}{l}\text { Demir } \\
(2014)\end{array} \quad \& \quad$ Bahadir & Turkey & Compliance is also significantly associated with the level of leverage \\
\hline C. Internationalit & & \\
\hline Author(s) & Country & Results \\
\hline Glaum \& Street (2003) & Germany & Internationality not significantly related to level of compliance with IFRS \\
\hline $\begin{array}{l}\text { Ali, Ahmed \& Henry } \\
(2004\end{array}$ & South Asia & $\begin{array}{l}\text { Compliance levels are positively related to multinational company status } \\
\text { (internationality) }\end{array}$ \\
\hline $\begin{array}{l}\text { Al-Shammari (2011) } \\
\text { D. Auditor Type }\end{array}$ & Kuwait & Level of compliance with IFRS is associated positively with internationality \\
\hline Author(s) & Country & Results \\
\hline Glaum \& Street (2003) & & $\begin{array}{l}\text { Compliance with IFRS disclosures is positively related to firms being audited by Big } 4 \\
\text { auditing firms }\end{array}$ \\
\hline $\begin{array}{l}\text { Ali, Ahmed \& Henry } \\
\text { (2004) }\end{array}$ & South Asia & Quality (type) of auditors are found to be insignificant in explaining the compliance level. \\
\hline $\begin{array}{l}\text { Al Mutawaa \& } \\
\text { Hewaidy }(2010)\end{array}$ & Kuwait & $\begin{array}{l}\text { Type of auditor has no significant association with level of compliance with IAS-led } \\
\text { (IFRS) disclosure requirements. }\end{array}$ \\
\hline Al-Shammari (2011) & Kuwai & Level of compliance with IFRS is associated positively with auditor type. \\
\hline Juhmani (2012) & Buhrain & $\begin{array}{l}\text { Audit firm size (type of auditor) has a significant positive relationship with the level of } \\
\text { compliance with mandatory IFRS disclosure requirements. }\end{array}$ \\
\hline Palmer (2013) & Australia & A positive relationship between the extent of disclosure and auditor size (type), \\
\hline $\begin{array}{l}\text { Demir } \\
(2014)\end{array} \quad \& \quad$ Bahadir & Turkey & Compliance with IFRSs disclosures is positively related to firms being audited by Big 4 \\
\hline
\end{tabular}

\section{Research Methods}

This study employs ex-post facto descriptive research design. The population is made up of 57 (fifty seven) financial services companies listed on the Nigerian Stock Exchange (NSE) as at $31^{\text {st }}$ December, 2014. The population is made up of 17 (seventeen) Deposit Money Banks (DBM) and 40 (forty) insurance companies (INC). However, a sample of 31 (thirty one) companies divided into 14 (fourteen) DBM and 17 INC listed on the NSE as at 31 December, 2014 is utilized for the study. The only filter used for the inclusion of a firm in the sample is the availability of its annual report and accounts in the public domain.

Secondary data for the sampled firms were obtained from the annual financial statements and related notes to the accounts. The instrument employed for collation of the secondary data is a checklist developed by Ernest \& Young and KPMG for the financial services sector. The checklist is divided into a number of sections, namely (i) general presentation of financial information, (ii) statement of financial position, (iii) statement of profit or loss and other 
comprehensive income, (iv) statement of cash flows, (v) components of cash flows and cash equivalent, (vi) statement of changes in equity, (vii) acquisition of subsidiaries and business units, (viii) notes to the financial statements, and (ix) special topics.

The data for the study were analysed using descriptive statistics, Ordinary Least Square (OLS) regression technique and Wilcoxon Rank Sum Test for two independent samples. Descriptive statistics was used to address objective one which seeks to establish the level of compliance with the mandatory disclosure requirements of IFRS by listed financial services companies in Nigeria. The mean score is used to gauge the level of compliance with IFRS where a grading criterion A, B, C, and D is used (see Saidu and Dauda, 2014). 'A' stands for mean scores between 80-100\%, representing 'Strongly Complied'. 'B' stands for mean scores between $60-79 \%$, representing 'Semi Strongly Complied'. ' $\mathrm{C}$ ' stands for mean scores between 40-69\%, representing 'Poorly Complied'. ' $\mathrm{D}$ ' stands for mean scores between $0-39 \%$, representing 'Non-Compliance'. The OLS multiple regression technique is used to address objective two which seeks to establish the relationship between firm characteristics and the level of compliance with IFRS by listed financial services companies in Nigeria. Lastly, the Wilcoxon Rank Sum Test for two independent samples is used to address objective three which seeks to establish whether significant differences exist in the compliance levels by listed DMB and INC in Nigeria.

The study has both the dependent and independent variables in order to ascertain the relationship between firm characteristics and compliance with IFRS. The dependent variable, level of compliance with IFRS, is represented by Corporate Compliance Index (CCI). This study adopts the "dichotomous" disclosure index approach in which a value of one is assigned if the company discloses an item of information and zero, otherwise in line with Al-Shammari (2011) and Juhmani (2012). When a disclosure is deemed irrelevant for a specific company, the item is ignored in the computation of the index for that company. The corporate compliance score for company $\mathrm{X}$ is computed as follows:

$$
\operatorname{CCSx}=\sum_{t=0}^{n} \mathrm{Ix}
$$

where,

CCSx $=$ Corporate compliance score for company $\mathrm{X}$

$\mathrm{I}(\mathrm{x})=$ Company $\mathrm{X}$ score for the disclosure item where 1 (one) score is given for disclosure and 0 (zero) score for non-disclosure.

$\mathrm{n}=$ the maximum score to be achieved.

The un-weighted corporate compliance index (CCIx) for company $\mathrm{X}$ will be calculated by dividing its score $\left(\mathrm{CCS}_{\mathrm{x}}\right)$ over maximum score as follows:

\section{$\mathrm{CCIx}=\mathrm{CCSx} /$ Maximum score}

where

CCIx and CCS are as previously defined.

The independent variables, firm characteristics, are proxy by firm size, profitability, leverage, internationality, and auditor type. The table below sets out how each of the independent variables is measured.

Table 2. Independent Variable Measurement and Abbreviation

\begin{tabular}{llc}
\hline Variables & Measurement & Abbreviation \\
\hline Size & Total Assets & SIZ \\
Profitability & Earnings Per Share & PRO \\
Leverage & Total Debts/Total Equity & LEV \\
Internationality & Dichotomous variable denoted by 1 & INT \\
& (one) if company operates in more than & \\
one country, and 0 (zero) otherwise. & AUD \\
Auditor type & $\begin{array}{l}\text { Dichotomous variable denoted by 1 } \\
\text { (one) if the auditor is among the Big4, } \\
\text { otherwise 0 (zero). }\end{array}$ & \\
\hline
\end{tabular}

The linear relationship between the dependent and independent variable is expressed in the multiple regression model as follows:

$\mathrm{CCI}=\beta_{0}+\beta_{1} \mathrm{SIZ}+\beta_{2} \mathrm{PRO}+\beta_{3} \mathrm{LEV}+\beta_{4} \mathrm{INT}+\beta_{5} \mathrm{AUD}+\mathrm{e} \quad-\quad-\quad-$

where, 
$\mathrm{SIZ}=$ Firm Size

$\mathrm{PRO}=$ Profitability

LEV $=$ Leverage

INT $=$ Internationality

AUD $=$ Auditor Type

$\mathrm{CCI}=$ Corporate Compliance Index

$\beta_{0}=$ Intercept of the model

$\beta_{1}, \beta_{2}, \beta_{3}, \beta_{4}, \beta_{5}=$ the regression coefficients

$\mathrm{e}=$ Error term

The a priori expectation is that $\beta_{1}, \beta_{2}, \beta_{3}, \beta_{4}, \beta_{5}>0$

\section{Results and Discussion}

This section presents and discusses the results obtained from the statistical tests. The results presented are in respect of descriptive statistics, regression analysis and the Wilcoxon Rank Sum Test for two independent samples. Table 3 presents the descriptive statistics in respect of the mean, standard deviation, minimum and maximum value.

Table 3. Descriptive Statistics for all Variables

\begin{tabular}{lrrrr}
\hline Variable & Minimum & Maximum & Mean & Std Deviation \\
\hline CCI & 0.7572 & 0.9320 & 0.8594 & 0.0488 \\
SIZ (billions) & 2.148 & 4,131 & 824 & 1,750 \\
PRO (kobo & -17.35 & 316.00 & 46.32 & 73.77 \\
LEV & -1.55 & 9.74 & 3.800 & 3.347 \\
INT & 0 & 1 & 0.26 & 0.455 \\
AUD & 0 & 1 & 0.65 & 0.486 \\
\hline
\end{tabular}

Source: Summary of SPSS Version 20.0 Output

The table shows a mean value of 0.859 for CCI which suggests $85.9 \%$ compliance with IFRS by the sample of listed financial services companies in Nigeria. The compliance level reported in this study (85.9\%) is higher than those documented in other jurisdictions such as the Middle East (69\%), Kuwait (69\% \& 82\%), Turkey (79\%), Buhrain (80.7\%) (see Ibrahim, 2006; Al Mutawaa \& Hewaidy, 2010; Al-Shammari, 2011; Demir \& Bahadir, 2014; Juhmani, 2012 respectively). The minimum and maximum values of $\mathrm{CCI}$ are $75.7 \%$ and $93.2 \%$ respectively. The standard deviation of $\mathrm{CCI}$ is 0.049 which shows that compliance of the sampled companies with IFRS is not widely dispersed. The 0.859 mean value of CCI further implies that compliance with IFRS by listed financial services companies in Nigeria is very high. The high compliance level vitiates the arguments that Nigeria was ill-prepared to adopt IFRS in 2012 due to lack of educational and technical competencies to implement the project (see Herbert \& Tsegba, 2013). The compliance level is higher than the one reported by Saidu and Dauda (2014) who investigated, amongst others, the level of compliance with IFRS 1 by DMB in Nigeria. The disparity in the reported compliance levels could be attributed to two factors. Firstly, Saidu and Dauda (2014) focused on listed DMB only while the present study includes a large sample consisting of both listed DMB and insurance companies in Nigeria. Secondly, the instrument used to collect data for compliance index computations in the two studies differs. Saidu and Dauda (2014) used the provisions of IFRS 1 only, while this study covers all the provisions of IFRS related to the financial services sector.

Table 3 also shows a mean size of N824 billion for the sampled financial services companies in Nigeria measured in terms of total assets. The minimum and maximum values of size are $\mathrm{N} 2.148$ billion and N4, 131billion respectively. The minimum and maximum value of firm size suggests a wide disparity in the size of sampled firms. The table also shows that the profitability of the sampled companies ranges from a minimum of -17.3kobo to a maximum of 316 kobo while the mean value stood at 46.32kobo. The minimum and maximum values of the sampled listed financial services companies in Nigeria are -1.55 and 9.74 respectively with the mean value standing at 3.80 .

Furthermore, Table 4 presents the correlation matrix and the variance inflation factor (VIF) for all the independent variables used in the study. 
Table 4. Correlations and Variance Inflation Factor (VIF)

\begin{tabular}{lllllll}
\hline & SZ & PF & LEV & INT & AUD & VIF \\
\hline SIZ & 1.000 & & & & & 1.473 \\
PRO & 0.346 & 1.000 & & & & 1.309 \\
LEV & 0.685 & 0.312 & 1.000 & & & 1.314 \\
INT & 0.453 & 0.157 & 0.237 & 1.000 & & 1.333 \\
AUD & 0.496 & 0.374 & 0.388 & 0.283 & 1.000 & 1.662 \\
\hline
\end{tabular}

Source: Summary of SPSS Version 20.0 Output

From the table, the highest correlation is 0.685 which is between SIZ and LEV but is less than the threshold that is harmful for regression analysis. The low correlation among the independent variables is an indication that multicollinearity may not be a problem to the study. The suggestion in the empirical literature is that correlation between the independent variables is considered undesirable for multivariate analysis only if it exceeds 0.8 (see Barako \& Tower; 2006; Gujarati \& Sangeetha, 2007).To further confirm the absence of multicollinearity among the independent variables, variance inflation factor (VIF) was used. The VIF for all the variables is less than 3 which is far less than 10 considered harmful for regression analysis (ibid). The correlation matrix and the VIF values, therefore, suggest that multicollinearity does not present a challenge in this investigation.

Before subjecting the dataset to OLS regression analysis, data normality test was carried out using skewness statistics. Result of the test is presented in Table 5. The table shows that CCI, LEV and AUD are normally distributed since the values of their respective skewness statistics is between their respective two times standard error ( $\pm 2 \mathrm{SE})$. However, SIZ, PRO and INT are not normally distributed because their skewness statistics fall outside the range of their two times standard error. Consequently, the dataset for SIZ, PRO and INT was transformed using natural logarithm to normalize the dataset preparatory for regression analysis.

Table 5. Skewness Analysis

\begin{tabular}{lrcc}
\hline \multicolumn{1}{c}{ Variable } & Statistics & Std Error & \pm 2 SE \\
& & & \\
\hline CCI & -0.560 & 0.421 & 0.842 \\
SIZ & 1.489 & 0.421 & 0.842 \\
PRO & 2.220 & 0.421 & 0.842 \\
LEV & 0.338 & 0.421 & 0.842 \\
INT & 1.163 & 0.421 & 0.842 \\
AUD & -0.638 & 0.421 & 0.842 \\
\hline
\end{tabular}

Source: Summary of SPSS Version 20.0 Output

In addition, Table 6 presents the result of the regression analysis carried out on the data to ascertain the relationship between firm characteristics and compliance with IFRS.

Table 6. Regression Results

\begin{tabular}{cccr}
\hline & Standardized Beta & t-statistics & P-value (Two-tailed) \\
\hline SIZ & 0.290 & 1.490 & 0.149 \\
PRO & 0.325 & $1.775^{*}$ & 0.088 \\
LEV & -0.108 & -0.585 & 0.564 \\
INT & -0.103 & -0.557 & 0.582 \\
AUD & 0.246 & 1.193 & 0.244 \\
Adjusted R & & 0.23 & \\
F-Statistics & & $2.792^{* *}$ & 0.039 \\
\hline
\end{tabular}

**Significant at $5 \%$ level; *Significant at $10 \%$ level.

Source: Summary of SPSS Version 20.0 Output

The table shows an adjusted $\mathrm{R}^{2}$ of 0.23 which suggests that $23 \%$ of variation in the dependent variable, $\mathrm{CCI}$ is jointly explained by the independent variables. The F-Statistics of 2.792 is significant at $5 \%$ level $(0.039)$, implying that the model is fit to be used to explain the relationship between firm characteristics and compliance with IFRS. The regression results of the association between firm characteristics and level of compliance with IFRS of the sampled companies are discussed hereunder. 


\subsection{Firm Size and Compliance with IFRS}

Table 6 shows a positive (0.290) but insignificant relationship between firm size and compliance with IFRS by listed financial services companies in Nigeria based on a t- value of 1.490 and and p-value of 0.149 . The positive and insignificant association between company size and compliance with IFRS is consistent with the results of Glaum and Street (2003), and Demir and Bahadir (2014). The result, however, contradicts those of Ali, Ahmed and Henry (2004); Chavent et al. (2006); Ibrahim (2006); Fekete et al. (2008); Almutawaa and Hewaidy (2010); Alshammari (2011); Juhmani (2012): and Palmer (2013), who found a positive association that, is significantly related to disclosure compliance. The results do not support the agency and capital need theories which predict a significant positive relationship between company size and compliance with international accounting standards. The possible explanation for this inconsistency could be that compliance with IFRS by listed financial services companies in Nigeria is induced by legislation and not firm size. Based on the empirical evidence, the study fails to reject the hypothesis which states that firm size has no significant effect on compliance with IFRS by listed financial services companies in Nigeria.

\subsection{Profitability and Compliance with IFRS}

The table also shows that corporate profitability has a positive (0.325) and significant (at 10\%) relationship with IFRS compliance of sampled firms based on t-value and p- value of 1.775 and 0.088 respectively. This result is consistent with Ali et al. (2004), and Palmer (2013) which report a significant positive association between profitability and compliance with IFRS. The result is however, inconsistent with those of Chavent et al. (2006), Almutawaa and Hewaidy (2010), Juhmani (2012), and Demir and Bahadir (2014) who document insignificant positive association between corporate profitability and compliance with IFRS. Based on the evidence in respect of profitability, the study rejects the hypothesis which states that profitability has no significant effect on compliance with IFRS by listed financial services companies in Nigeria.

\subsection{Leverage and Compliance with IFRS}

Table 6 above indicates that corporate leverage has a negative (- 0.108) and insignificant effect on compliance with IFRS by sampled companies in view of a t- value of -0.585 and p- value of 0.564 . The result is consistent with the works of Ibrahim (2006); Ali et al. (2004); Almutawaa and Hewaidy (2010) and Juhmani (2012) that found an inverse relationship between leverage and firm compliance with IFRS. The finding is contrary to that of Chavent $e t$ al. (2006) and Palmer (2013) who found leverage to be positive and significant with disclosure compliance of firms. The result contradicts agency theory which suggests that agency costs are higher for companies with more debt and so expected to disclose more information with increase in leverage. Based on the available evidence, the study fails to reject the hypothesis which states that leverage has no significant effect on compliance with IFRS by listed financial services companies in Nigeria.

\subsection{Internationality and Compliance with IFRS}

The results in Table 6 also indicate that internationality has a negative (- 0.103) but insignificant effect on compliance with IFRS by sampled companies based on t- value of -0.557 and a p- value of 0.582 . The present result is consistent with that of Glaum and Street (2003) who found no significant relationship between internationality and compliance with the mandatory disclosure requirements of IFRS in Germany. The result is, however, inconsistent with the result of Ali et al. (2004) who found a significant positive relationship between internationality and compliance with IFRS mandatory disclosure requirements in South Asia. The result in respect of internationality negates the argument in extant literature which suggests that listed firms with foreign subsidiaries are financed with local and external capital and are more likely to comply with IFRS. Based on the empirical evidence, the study cannot reject the hypothesis which states that internationality has no significant effect on compliance with IFRS by listed financial services companies in Nigeria.

\subsection{Auditor Type and Compliance with IFRS}

Table 6 also reveals a positive (0.246) but insignificant effect of auditor type on compliance with IFRS by sampled companies based on t- value of 1.193 and p- value of 0.244 . This result is consistent with prior studies by Ali et al. (2004) and Almutawaa and Hewaidy (2010), who found no significant association between type of auditor and extent of disclosure compliance. The result contradicts the arguments that large and well-known audit firms (such as the "Big Four") encourage their customers to comply with disclosure in order to supply maximum information (Dumontier \& Raffournier, 1998). Based on the available evidence, the study fails to reject the hypothesis which states that auditor type has no significant effect on compliance with IFRS by listed financial services companies in Nigeria.

Furthermore, to determine whether significant differences exist in the level of compliance with IFRS by listed DMB and INC in Nigeria, the descriptive statistics of the sampled companies was compared. Table 7 presents the descriptive statistics for corporate compliance with IFRS by listed DMB and INC in Nigeria. 
Table 7. Descriptive Statistics of Corporate Compliance Index (CCI) by Deposit Money Banks and Insurance Companies

\begin{tabular}{llllll}
\hline Variable & No. & Minimum & Maximum & Mean & Std Deviation \\
\hline DMB & 14 & 0.8155 & 0.9320 & 0.8732 & 0.0368 \\
INC & 17 & 0.7572 & 0.9320 & 0.8480 & 0.0554 \\
\hline
\end{tabular}

Source: Summary of SPSS Version 20.0 Output

The table shows that compliance by listed DMB in Nigeria ranges from a minimum of 0.8155 (or $81.55 \%$ ) to a maximum of 0.9320 (or 93.20\%). The mean compliance with IFRS of listed DMB in Nigeria is 0.8732 (or 87.32\%) while the standard deviation stood at 0.036 . The descriptive statistics in respect of listed DMB in Nigeria suggests high level of compliance with low dispersion among them. The table also shows that compliance with IFRS by listed INC in Nigeria ranges from a minimum of 0.7572 (or 75.72) to a maximum of 0.9320 (or 93.20\%). The mean compliance with IFRS of listed INC in Nigeria is 0.8480 (or $84.80 \%$ ) while the standard deviation is 0.0554 . The descriptive statistics in table 7 reveal that compliance by the INC is lower and more widely dispersed than compliance by DMB. The descriptive statistics also indicate that DMB belong to 'A' grade of compliance which implies that listed DMB in Nigeria are strongly complying with IFRS disclosure requirements. In contrast, listed INC in Nigeria belong to ' $\mathrm{B}$ ' grade of compliance which suggests semi Strong compliance with IFRS disclosure requirements.

To determine whether the differences in compliance with IFRS disclosure requirements between listed DMB and INC in Nigeria are significant, Wilcoxon Rank Sum Test for two independent samples was conducted. The results are presented in table 8 below.

Table 8. Wilcoxon Rank Sum Test Results

\begin{tabular}{llll}
\hline Variable & No. & Mean Rank & Sum of Ranks \\
\hline DMB & 14 & 17.61 & 249.50 \\
INC & 17 & 14.68 & 246.50 \\
Wilcoxon W & & & 249.50 \\
Z & & & -0.898 \\
P-value (2-tailed) & & & 0.369 \\
\hline
\end{tabular}

Source: Summary of SPSS Version 20.0 Output

The table shows that the mean rank for listed DMB is more than the mean rank of INC in Nigeria. This result corroborates the descriptive statistics which earlier revealed a higher compliance with IFRS by listed DMB than INC in Nigeria. However, the p-value of (0.369) for differences in compliance shows that the differences in compliance with IFRS between listed DMB and INC in Nigeria is not significant.

\section{Conclusion and Recommendations}

This study sought to achieve three main objectives, namely (i) ascertaining the level of compliance with IFRS by listed financial services companies in Nigeria, (ii) examining the effect of firm characteristics on IFRS compliance, and (iii) determining whether compliance with IFRS by DMB is significantly different from that of INC. Based on the results of data analyses and the findings, the paper makes these conclusions. Firstly, listed financial services companies in Nigeria have achieved high levels of compliance with IFRS despite arguments in the literature which suggested that Nigeria was ill-prepared to have adopted IFRS with effect from 2012. Secondly, profitability has a significant effect on compliance with IFRS. This finding is consistent with the signaling theory which posits that companies that are performing well have the incentives to disclose more information to signal their good performance. Thirdly, size, leverage and internationality have no significant effect on IFRS compliance. These findings contradict both the agency and capital need theories; they also call for further investigation. Fourthly, insignificant differences exist in the level of compliance with IFRS between DMB and INC. On a whole, compliance with IFRS by listed financial services companies in Nigeria appears to be driven by legislation and not by firm characteristics. In spite of the high level of compliance with IFRS reported in this study, it is recommended that the regulatory authorities such as the Financial Reporting Council of Nigeria (FRCN), the Nigerian Stock Exchange (NSE), and the Securities and Exchange Commission (SEC) should ensure strict monitoring and enforcement of compliance with IFRS by all listed firms in Nigeria to engender more compliance.

\section{Acknowledgement}

The authors highly appreciate the useful comments and suggestions from the participants at the $6^{\text {th }}$ Annual Conference 
of the African Accounting and Finance Association held in Strathmore University, Nairobi-Kenya, from $30^{\text {th }}$ August, to $2^{\text {nd }}$ September, 2016.

\section{References}

Akerloff, G. (1970). The market for lemons: quality, uncertainty and the market mechanism. Quarterly Journal of Economics, 84(3), 488-500. https://doi.org/10.2307/1879431

Akhtaruddin, M. (2005). Corporate mandatory disclosure practices in Bangladesh. The International Journal of Accounting, 40, 399-422. https://doi.org/10.1016/j.intacc.2005.09.007

Ali, M. J., Ahmed K., \& Henry, D. (2004). Disclosure compliance with national accounting standards by listed companies in South Asia, Accounting and Business Research, 34(3), 183-199. https://doi.org/10.1080/00014788.2004.9729963

Al-Mutawaa, A., \& Hewaidy, A. M. (2010). Disclosure level and compliance with IFRS: An empirical investigation of Kuwaity Companies. International Business \& Economics Research, 9(5), 33-50.

Al-Shammari, B. (2011). Factors influencing the extent of mandatory compliance with International Financial Reporting Standards: The Case of Kuwaiti Listed Companies, Journal of International Business and Economics, 11(4), 11-31.

Azobu, M. (2010). Adoption of IFRS in developing countries. International Journal of Business and Management, 7(3), 155-157.

Ball, R. (2006). International Financial Reporting Standards (IFRS): Pros and Cons for Investors. Accounting and Business Research, International Accounting Policy Forum, 5-27. https://doi.org/10.1080/00014788.2006.9730040

Barako, D. G., \& Tower, G. (2006). Corporate Governance and Bank Performance: Does Ownership Matter? Evidence from Kenyan Banking Sector. Corporate Ownership and Control, 4(2), 133-144.

Belkaoui, A., \& Karpik, P. G. (1989). Determinants of corporate decision to disclose social information. Accounting, Auditing and Accountability Journal, 2(1), 36-51. https://doi.org/10.1108/09513578910132240

Chavent, M., Ding, Y., Fu, L., Stolowy H., \& Wang H. (2006). Disclosure and determinants studies: An extension using the divisive clustering Method (DIV). European Accounting Review, 15(2), 181-218. https://doi.org/10.1080/09638180500253092

Demir, V., \& Bahadir, O. (2014). The extent of compliance with International Financial Reporting Standards (IFRS) by listed companies in Turkey. Accounting and Management Systems, 13(1), 4-34.

Dockery, E., Herbert, W. E., \& Taylor, K. ((2000). Corporate governance, managerial strategies and shareholder wealth maximization: A study of large European companies. Managerial Finance, 26(9), 21-35. https://doi.org/10.1108/03074350010766855

Dumontier, P., \& Raffournier, B. (1998). Why firms comply voluntarily with IAS: An empirical analysis with Swiss data, Journal of International Financial Management and Accounting, 9(3), 216-245. https://doi.org/10.1111/1467-646X.00038

Fekete, S., Matis, D., \& Lukacs, J. (2008). Factors influencing the extent of corporate compliance with IFRS. The case of Hungarian listed companies. Available at ssrn.com/abstract=1295722.

Glaum, M., \& Street, D. L. (2003). Compliance with the disclosure requirements of Germany's new market: IAS Versus US GAAP, Journal of International Financial Management and Accounting, 14(1), 64-100. https://doi.org/10.1111/1467-646X.00090

Gujarati, D. N., \& Sangeetha (2007). Basic Econometrics. Singapore: McGraw-Hill International Edition.

Healy, P. M., \& Palepu, K. G. (2001). Information asymmetry, corporate disclosure, and the capital markets: a review of the empirical disclosure literature. Journal of Accounting and Economics, 31(13), 405-440. https://doi.org/10.1016/S0165-4101(01)00018-0

Herbert, W. E. (2010). Adoption of IFRS in Nigeria: Assessing the level of preparedness. A paper presented at FSS2020 retreat on IFRS, CBN Head Office Abuja, 13 December.

Herbert, W. E., \& Tsegba, I. N. (2013). Economic consequences of International Financial Reporting Standards (IFRS) adoption: Evidence from a developing country. European Journal of Business and Management, 5(28), 80-99.

Herbert, W. E., Tsegba, I. N., Ohannele, A. C., \& Anyahara, I. O. (2013). Adoption of International Financial Reporting Standards (IFRS): Insight from Nigerian academics and practitioners. Research Journal of Finance and Accounting, 4(6), 121-235. 
Ibrahim, A. (2006). Corporate Financial Reporting Reform in economies in transition: The extent of compliance with International Financial Reporting Standards disclosure requirements in Annual Reports. Ph.D. Thesis. Department of Accounting. University of Surrey Aleppo, Syria.

Jensen, C. M., \& Meckling, W. H. (1976). Theory of the firm: Managerial behavior, agency costs and ownership structure. Journal of Financial Economics, 3(4), 305-360. https://doi.org/10.1016/0304-405X(76)90026-X

Juhmani, O. I. H. (2012). Factors influencing the extent of corporate compliance with IFRS: Evidence from companies listed in Bahrain Stock Exchange, Journal of International Business and Economics, 12(2), 67-79.

Kam, V. (1990). Accounting Theory. John Wiley \& Sons.

Lev, B., \& Penman, S. H. (1990). Voluntary forecast disclosure, non-disclosure, and Stock Prices, 28(1), 49-76.

Nobes, C. (2006). The survival of international differences under IFRS: Towards a research agenda. Accounting and Business Research, 36(3), 233-245. https://doi.org/10.1080/00014788.2006.9730023

Palmer, P. D. (2013). The impact of adopting IFRS in Australia: The extent and quality of disclosures, and their relationship to corporate characteristics. School of Commerce Research Paper Series, 06-5 ISSN: 1441-3906.

Saidu, S., \& Dauda, U. (2014). An assessment of compliance with IFRS framework at first-time adoption by the quoted banks in Nigeria. Journal of Finance and Accounting, 2(3), 64-73.

Smith, A. (1776). An Inquiry into the Nature and Causes of the Wealth of Nations. https://doi.org/10.1093/oseo/instance.00043218

Veblen, T. (1924). The Engineers and the Price System. New York: Viking.

Watson, A., Shrives, P., \& Marston, C. (2002). Voluntary disclosure of accounting ratios in the UK. British Accounting Review, 34(4), 289-313. https://doi.org/10.1006/bare.2002.0213

\section{Copyrights}

Copyright for this article is retained by the author(s), with first publication rights granted to the journal.

This is an open-access article distributed under the terms and conditions of the Creative Commons Attribution license which permits unrestricted use, distribution, and reproduction in any medium, provided the original work is properly cited. 